\title{
A Comparative Study on Wastewater Treatment Methods of Selected Multinational and Local Beverage Companies in the Philippines and Their Effects on the Environment
}

\author{
Yolanda Aguilar, Edwin Tadiosa, and Josephine Tondo
}

\begin{abstract}
Abstrac - Waste water treatment is the process of removing existing contaminants to make water becomes fit for disposal or reuse. The waste water generally contains $99.9 \%$ water and $0.1 \%$ of solid impurities; thus, it has a large potential as a source of water for different purposes such as fish ponds, comfort rooms, cleaning source, among others. Treated water can be used back into the natural environment without adverse ecological impact. In the Philippines, the most commonly used treatment methods for beverage companies are pond/lagoon system and activated sludge system.

This study aimed to characterize and differentiate the wastewater treatment methods used by Coca-Cola Bottlers Company (CCBC) and the Tanduay Distillery, Inc. (TDI), a multi-national and local company, respectively. This study also aimed to identify the most effective and commercially viable treatment system as well as determine effective waste management system.

Study on waste water treatment systems in selected multi-national and local beverage companies in the Philippines are recommended with the end view of obtaining the effects of treated water in nearby communities where these companies are located. Industrial wastewater treatment is important to generate alternative source of water as well as to protect and maintain the balanced ecosystem in the community.
\end{abstract}

Index Terms-Wastewater, treatment system, beverage company, balanced ecosystem, organisms.

\section{INTRODUCTION}

Water plays a significant role in every organism on earth. It is a chemical sub-stance with a chemical formula of $\mathrm{H}_{2} \mathrm{O}$ which correspond to one oxygen and two hydrogen atoms. during precipitation [1].

On earth, about $70.9 \%$ is covered by water. It is found largely on oceans and other large bodies of water, with $1.6 \%$ of water below ground in aquifers and $0.001 \%$ in air as vapor, clouds and ocean which is the largest body of water comprises $97 \%$ of the surface water, glaciers and polar ice caps hold $2.4 \%$ and other land surface water as rivers, lakes and ponds consist of $0.6 \%$ [2].

In the Philippines, it is an archipelagic country consisting of 7,107 islands. It has total area of 300,000 square

Manuscript received February 14, 2014; revised May 2, 2014.

E. Tadiosa is with the Botany Division, National Museum of the Philippines, Manila.

Y. Aguilar is with the Mines and Geosciences Bureau, Department of Natural Resources, Quezon City, Philippines.

J. E. Tondo is with the Faculty of Science, Technology and Mathematics Philippine Normal University, Philippines (e-mail joswilshen25@yahoo.com). kilometres wherein 65 percent are coastal [3]. Environmental Management Bureau has classified 62 percent of 525 water bodies according to their intended beneficial usage. Only five are class AA which can be used for public water supply and most of the water bodies are classified as class $\mathrm{C}$ intended for fishery, recreation and supply for manufacturing processes. Water is use and reuse not only for domestic purposes; it is also being use in myriad tasks particularly in food and beverage industries [4].

Human uses water in various needs and processes [5].Water is important in agriculture due to irrigation. Irrigation plays a key component to produce crops. Irrigation takes up to $90 \%$ of water withdrawn in some developing countries and significant proportions in more economically developed countries [6]. Water is considerately very significant to human and other organisms for drinking purposes [7]. The human body contains from 55\% to $78 \%$ water, depending on body size. To function properly, the body requires between one and seven liters of water per day to avoid dehydration [8]. Other functions of water are the following: washing, chemical purposes, heat exchange, fire extinction, recreation and industrial applications such as food, water and beverage industries and processes [9].

Numerous factors which may lead to water pollution occurred in the environment [10]. Some of these factors of water pollution came from industrial plants, chemicals, household activities and other uses of water in the community [11].

Several multinational and local beverage companies are operating and functional in the Philippines. Water has a very essential role in these types of companies due water is the main constituent of their manufactured goods [12].

Two large companies were identified in this study namely Coca Cola Bottlers Philippines and Tanduay Distillers Incorporation. Water plays a significant role in these two beverage companies. It serves an important component of their products. As water being use for the manufactured beverages, water takes part in the waste of each company.

Industrial water treatment system can be classified into several categories such as boiler water treatment, cooling water treatment and waste water treatment [13]. Among the given water treatment, waste water treatment is use by beverage and other industrial companies. Basically, industrial water treatment deals with scaling, corrosion, microbial activity and disposal of residual wastewater [14].

Water treatment system has its essential role in beverage company [15]. Its main function is to make water more suitable for the desired end-use [16]. The main goal of 
wastewater treatment is to eliminate as much as of the suspended solids as possible before the remaining water called effluent and released back to the environment.

\section{The PROBlem AND ITS OBJECTIVES}

In the study conducted, the two leading multinational and local beverage companies used waste water treatment for the disposal or residual wastewaters such as biological oxygen demand and chemical oxygen demand from industrial plants. Both beverage companies produced sludge as a result of their production of non-alcoholic and alcoholic beverages. This study would like to find out if waste water treatment system is existing in both multinational and local companies found in the Philippines. And if the waste water treatment is existing, any similarities and/or differences may be identified between the two companies being studied.

The specific objectives of the study are as follows:

1) To find out and differentiate waste water treatment in selected multinational and local beverage companies in the Philippines.

2) To compare some significant information in relation to the waste water treatment in respective company. Some of this information are as follows:

a) The time water treatment system is being used and implemented.

b) b.Identify the system when waste water treatment system is not being used.

c) Department used to handle the water system treatment.

d) Accredited organization used to upgrade the water treatment system

e) Other ways where in the company help in maintaining, protecting and con-serving ecological system in the country

f) Philippine laws being practiced by the company to support the guidelines of water system.

g) Assurance of the maintenance of ecological balance in the community.

h) Effects of treated water in the respective areas of identified companies.

\section{Methodology}

There are five stages on the methodology of the study as presented below:

1) Letter of request to conduct study and submitted/send to respective person for the company.

2) Ocular and field visit occurred to the sites of the two companies.

3) Interview/survey study/pictures with questionnaires given to the authority

4) Analysis of gathered data based from interview/survey.

5) Draw conclusion from the collected information.

Letter of requests were given to the beverage companies prior to the schedule of interview and survey. Questionnaires were given to officer-in-charge in Safety and Environmental Office and Administration. Ocular and field visit were made. Interview-survey was done during the schedule of ocular and field visit. Gathered data were collated and analyzed in relation to the questions given to answer the problems of the study. After the collected data had been gathered and analyzed, conclusions had been drawn based from the interview.

\section{RESUlts AND DiscuSSION}

The study was conducted to determine the differences of water treatment sys-tem existing in selected multinational and local beverage companies in the country and to find out the procedures on how the water treatment is being used in order to protect and maintain the balance ecosystem in the community. Comparative study was also done in relation to the given questions during the interview.

These are the given answers to the questions during the interview.

1) When did the water treatment system started in your company?

Coca Cola Safety and Environment Manager Response:

- The water treatment system started in 1989 in Coca Cola and in Sta. Rosa Plant, it was started in November, 1992.Tanduay Environmental Head and Safety Response: The water treatment system started in September, 1996 in San Miguel, Manila.

2) During the time when water treatment system is not being use, what is the existing system prior to the management of water wastes from your company?

Coca Cola Safety and Environment Manager Response:

- CCBPI SRI is not operating until waste water treatment is operational.

Tanduay Environmental Head and Safety Response:

- Sludge is being thrown in the creek near the San Miguel, Manila.

3) What is water treatment system?

Coca Cola Safety and Environment Manager Response:

- Water treatment is a process to get rid of waste from water coming from the plant and to return the water back to the environment which is now clean and free from waste and no detrimental effect on organisms in the environment.

Tanduay Environmental Head and Safety Response:

- Water treatment is when water is to environment fit in the organisms in the com-munity.

4) Are there other department/s handles the water treatment system and facilities in your company? Are you importing people from abroad or local personnel to op-erate the whole system?

Coca Cola Safety and Environment Manager Response:

- Local Personnel handles the department. We have the Safety and Environment Department where they make sure that the procedures are followed and implemented.

Tanduay Environmental Head and Safety Response:

- Local workers are responsible for the department where in implementation of water treatment system is implemented. We have Department of Environment and Safety. 
5) What are the procedures of the system used in your water treatment? Is it an internationally or locally based system?

Coca Cola Safety and Environment Manager Response:

- We have the primary treatment and secondary treatment. In primary treatment, we have STF or Sessile Treaking Filter and MTR or the Methane Upflow Reactor. STF is use for the aerobic treatment while MTR is use for anaerobic treatment. Aeration is use after the STF and MTR. I will give you a copy of the water treatment diagram model which is being used by Coca Cola. Activated sludge is being used at the end of the process. We follow Standard Procedure of Treatment. All Coca Cola Plants have the water treatment system because it is a company requirement (Fig. 1).

STA. ROSA PLANT WASTE WATER TREATMENT PLANT DIAGRAM

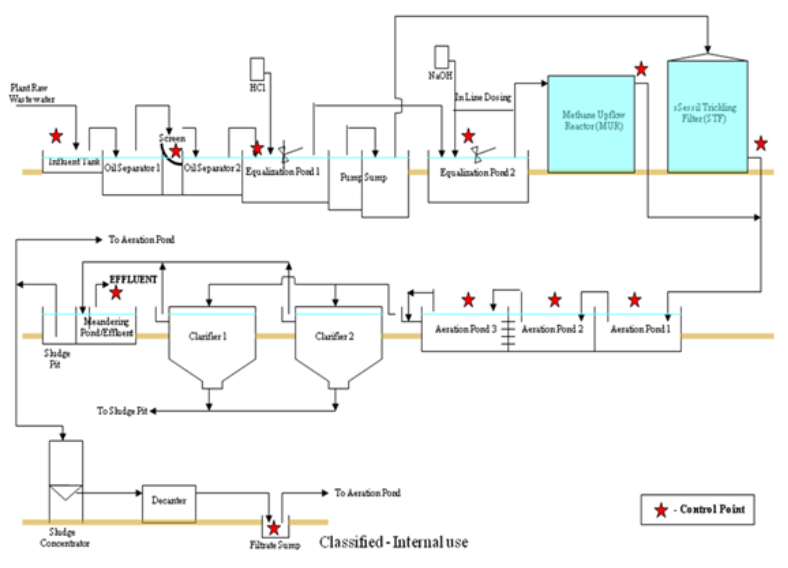

Fig. 1. Coca Cola Sta. rosa water treatment system diagram.

Tanduay Environmental Head and Safety Response:

- In the water treatment process, we have the collecting pit where in primary wastes are present, followed by Neutralization of the collected sludge. Aeration is present after the process then settlers are used where in all settled materials will be thrown in Drying bed to Sump Pit.

The company followed the Standard Method for Treatment. The company also uses Standard Method for Examination of Water and Waste by Eaton as the reference (Fig. 2).

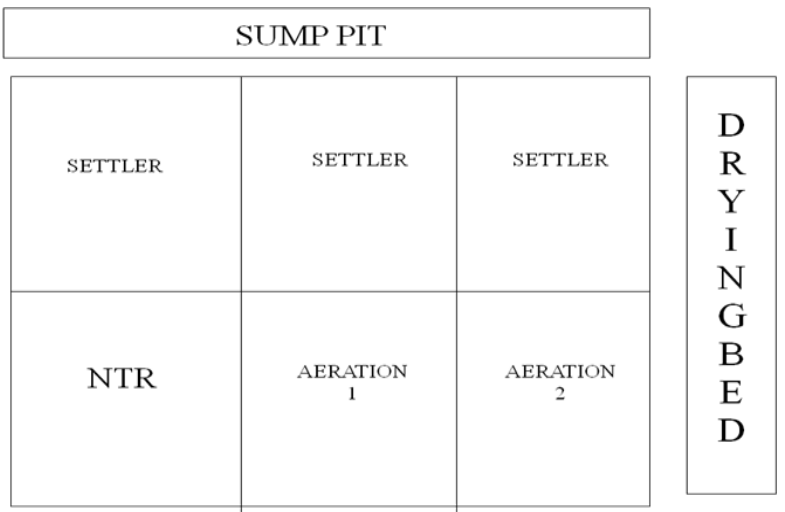

Fig. 2. Tanduay Distillers Inc. water treatment system diagram.

6) Any accredited organization/s used to upgrade and verify water treatment sys-tem? What is the duration of treatment and checking of systems done by accredited organizations?

Coca Cola Safety and Environment Manager Response:

- The company has local accredited organizations such as Department of Environment and Natural Resources (DENR). Under DENR, FABCON and LLDA (Laguna Lake Development Authority used to check the water treatment as well as the end result from water treatment. For international organization, we have the ISO 14001 and the main base of Coca Cola is in Atlanta, USA.

Tanduay Environmental Head and Safety Response:

- Local/Internal organizations checked the water treatment procedures and output. Laguna Lake Development used to test the water treatment results. The company's huge area is in Cabuyao Laguna. So far, we are now working in getting international certification like ISO.

7) With the present water treatment system you have right now, what is/are the contributions of your company in congruence to maintain the balance ecological status in the community? Please cite examples of these contributions.

Coca Cola Safety and Environment Manager Response:

- Maintaining and protecting the aquatic organisms (plants and animals). The company ensures that all water out from the plant is compliant to all components of the natural environment and regulated by the company.

Tanduay Environmental Head and Safety Response:

- Maintaining the creek (Estero de San Miguel) clean by throwing treated water coming from the plant.

8) In the present environmental condition today, does your company have other tools and means in maintaining, protecting and conserving ecological system in the country?

Coca Cola Safety and Environment Manager Response:

- At present, the company is compliant with the rules and implementing the water must be return in the environment without any detrimental effect to the natural environment. The company has its own pond where in water will be thrown from the plant. So far, the pond here in Sta. Rosa is 1 hectare. Once, we would like to throw water in the main body of water, the water must be treated again.

Tanduay Environmental Head and Safety Response:

- At present, the company may consider that water thrown in the environment is clean. The company is doing water treatment before it will be thrown in the creek (Estero de San Miguel).

9) Do you have any Philippine Laws that your company is practicing aside from the guidelines of water system you have?

Coca Cola Safety and Environment Manager Response:

- The company is following Clean Water Act Republic Act 9275 and the Development Administration Order No.35 and Revised Effluent Regulation of 1992.

Tanduay Environmental Head and Safety Response: 
- The company follows the procedures given by the government like Clean Water Act.

10) Aside from being the top beverage company, how can you assure the mainte-nance of ecological balance in your community?

\section{Coca Cola Safety and Environment Manager Response:}

- Aside from the company has its own pond where in treated water is being thrown, the company is doing Reuse, Reduce, Recycle and Replenish. Water in the company is being recycled to different comfort rooms and monitor water use. Aside from the 4R's, coastal cleanup, tree planting. Coca Cola has the commitment to return used water which is not harmful to the natural environ-ment. The said projects were initiated in line with the policy of "Live Positively" under The Coca Cola Company-Atlanta, Georgia USA, where in environmental protection and conservation is highly observed.

\section{Tanduay Environmental Head and Safety Response:}

- Aside from the water treatment system, the company is awarded several times due to the compliance of the company. Clean estero project was done and the company has the Adopt Cabuyao River Project. It was noted that the main company of Tanduay is in Cabuyao Laguna.

\section{SUMMARY AND CONCLUSION}

Water treatment exhibited a significant function to industrial companies. Primary, secondary treatment and activated sludge were used in selected multinational and local companies.

Two companies were studied in relation of the types and procedures of water treatment they are using. Both companies used functional water treatment system respectively.

The researcher gave letter of requests for the ocular and field visit together with the interview of the person-in-charge for the water treatment. Respective dates were given to each company for the interview and field study. Collation of data and information were gathered and validated from the given questions for the company. Conclusions were drawn based from the ocular and field visit with interview.

From the results of the study, the researcher has arrived at the following conclusions:

1) Water treatment systems were established and used by companies only in the year of 1992 and 1996.

2) Multinational company considered first the presence of waste water treatment system until it became operational.

3) Local personnel used to manage the water treatment system on each company with the Department of Environment and Safety. Aside from personnel in charge, local organizations supervised each company such as Department Of Environment and Natural Resources, Laguna Lake Development Authority and FABCON.

4) Both companies used water treatment with respective procedures such as primary treatment, secondary treatment and activated sludge. However, different methods were used by each company.

5) Multinational Company has already the International Standard Certification such as ISO 14001 aside from certifications locally while local company is pursuing to have certifications internationally. Local company received certifications from local organizations. However, they are now attempting to obtain international certification like ISO.

6) Based on the interview, as the plant discharged treated waste water in the natural environment such as in rivers and seas, the company is oblige to pay amount corresponding to the measurement of treated water the water treatment released. According to the Head of Environment and Safety, flow meter is a device used to measure the amount of water released in creek. After the release, it is a requirement to pay the corresponding amount to Laguna Lake Development Authority. Same through the Multinational Company.

7) Both companies are doing their responsibilities to protect and maintain the balance ecosystem in the community. Aside from the existing functional water treatment systems and facilities, both companies have their own means of con-serving the ecological system such as tree planting, coastal cleanup drive, adopt a river project and others. However, local companies should also invest funds to have own pond which will catch the water coming from the plants instead of throwing it directly in the bodies of water in the surrounding.

8) Based on the preliminary study, it was noted from both companies that there is no detrimental effects of waste water treated in the environment. Catch basin man-made pond which support living fauna such as tilapia and other aquatic organisms. Hence, the other company mentioned that water thrown in Estero de San Miguel is said to be treated and so it will not give any damaging effects to the organisms in the said ecosystem.

9) Both companies comply in the Philippine Laws in relation to water conservation and protection.

\section{RECOMMENDATIONS}

Considering the limited scope of this study, the researcher recommends further studies specifically in the following areas of research:

1) Consider some ecological tests and parameters in water by the researcher to conform with this preliminary study that there is no detrimental effects occurring in the area near to the two companies.

2) Assess other possible factors which may contribute the water pollution occurring near the vicinity of the two beverage companies such as contaminants from domestic or household areas.

3) As part of the study, the researcher recommends that domestic and household areas in urban vicinity must have a centralized waste water treatment system which should be provided by the local government unit.

4) Include other Multinational and Local Beverage companies in the Philippines in the study. 


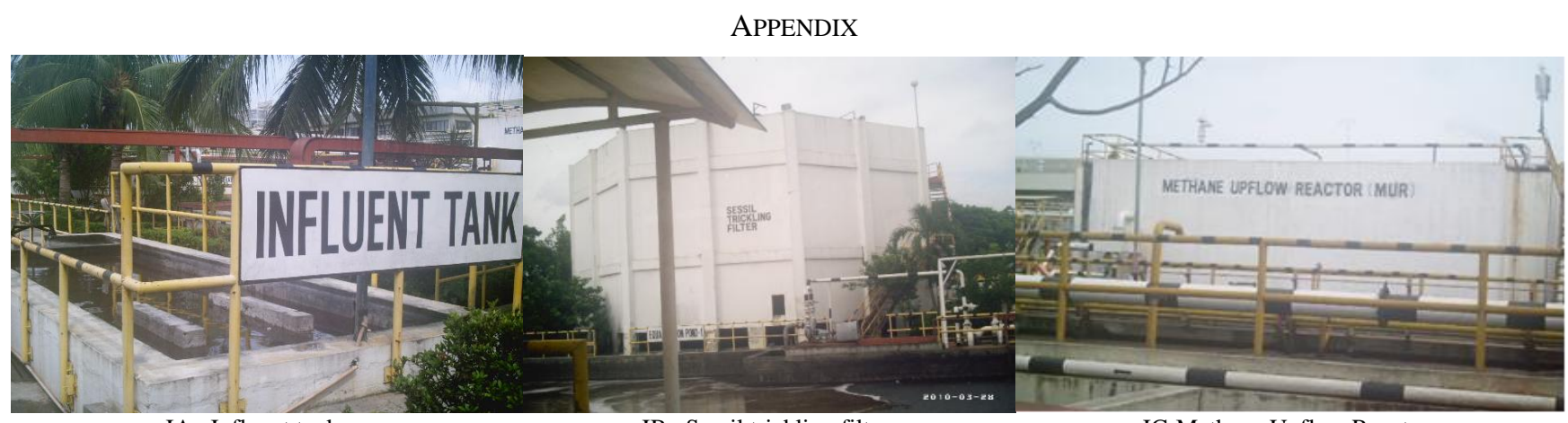

IA -Influent tank.

IB -Sessil trickling filter.

IC-Methane Upflow Reactor

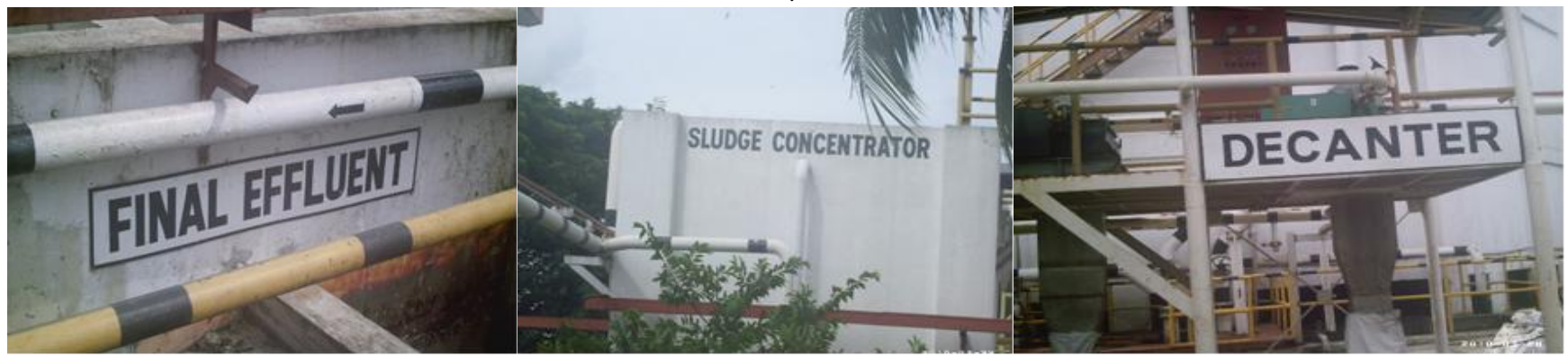

ID-Final Effluent

IE -Sludge Concentrator

IF -Decanter

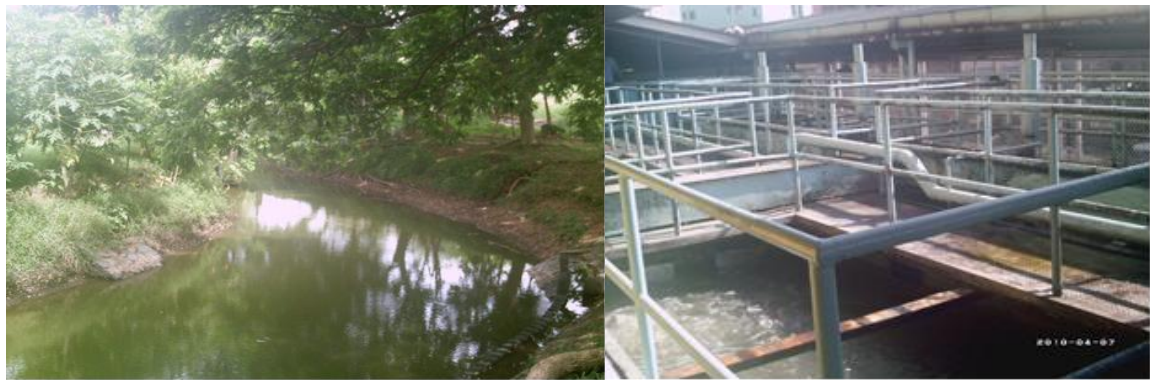

IG - Catch Basin(Man-made pond).

II A - Settler 1, 2, 3. Neutralization and Aeration.

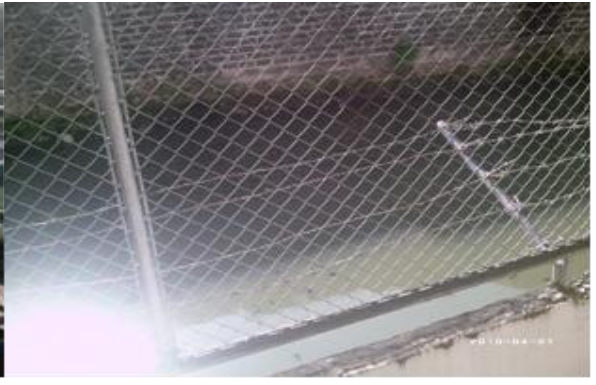

II B - Creek nearby.

\section{ACKNOWLEDGMENT}

This study would like to acknowledge the support of Dr. Yolanda Aguilar and Dr. Edwin Tadiosa for their support and to the Multinational and Local Companies for allowing to get significant data for the study.

\section{REFERENCES:}

[1] L. G. Su, "Impact on drinking water sources in close proximity to the payatas dumpsite," J. Public Health, Philippines, vol. 15, pp. 51-55, 2007.

[2] A. Birol, "Estimating the values of improved wastewater treatment: The case of River Ganga, India," International Food Policy Research Institute, USA, 2009.

[3] J. M. Tupas, "Clear plan to avert water crisis urged," The Environment Report, January 30, 2007.

[4] V. Cabading, Water Quality Treatment in the Philippines, Environmental Management Bureau, 2005.

[5] S. Molintas, "The Philippine indigenous peoples' struggle for land and life: Challenging legal texts," Arizona Journal of International and Comparative Law, vol. 21, no. 1, pp. 269-306, 2004.

[6] V. Valdez, "Decentralized Wastewater Treatment Systems for the San Fernando Slaughterhouse," ABORDA DEWATS Project in the Philppines, KOICA, UNEP and CAPS, pp. 1-6, 2011.

[7] R. Ramesh and N. Narayanasamy, "Cost of Unaccounted For Water-An Empirical Study in Tamil Nadu," Journal of Waste Water Treatment and Analysis, vol. 1, issue 1, 2006.

[8] WHO, Guidelines for Drinking-water Quality-Volume 1: Recommendations, $3^{\text {rd }}$ ed. ISBN 9241546964, 2006.

[9] Cariño and Delmar, "Cordillera watersheds face extinction," The Environment Report, January 4, 2007.
[10] Revised Water Usage and Classification Water Quality Criteria, DENR Administrative Order No. 34, Series of 1990, 1990.

[11] Revised Effluent Regulations of 1990, Revising and Amending The effluent Regulations of 1982, Implementing Rules and Regulations of Republic Act No. 9275, The Philippine Clean Water Act, DENR Administrative Order No. 35, Series of 1990, 1990.

[12] D. U. Sangari, "An Evaluation of Water and Land Uses in the Kano River Project, Phase I, Kano State," J. Appl. Sci. Environ. Manage., vol. 11, no. 2, pp. 105 - 111, June 2006.

[13] J. Dixon, Key Risks Facing the Beverage Industry, CSR Asia, 2010.

[14] J. Kandasamy and K. Karthikeyan, "Upflow Anaaerobic Sludge Blanket(UASB) Reactor in WasteWater Treatment, Water and Wastewater Treatment Technologies," Encyclopedia of Life Support Systems(EOLSS), 2010.

[15] L. Lumbao, Local Initiatives for Affordable Wastewater Treatment, USAID, 2010.

[16] P. H. Potgieter, "Water and energy in South Africa-managing scarcity," Journal of Envirronmental Management and Tourism, ASERS Publishing, p. 166, 2010.

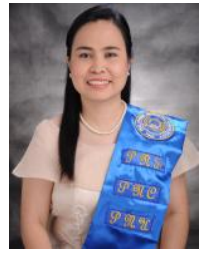

Josephine Pantanilla Espinoza Tondo is the author of this study. She hails from Bulacan, Philippines and born on July 9,1978 . She is a graduate with the master degree of science at University of Santo Tomas, Manila Philippines and now pursuing her doctorate degree in science education at Philippine Normal University, Manila, Philippines.

At present, she is connected as a faculty at Philippine Normal University in Faculty of Science, Technology and Mathematics as Biology Coordinator and Faculty in Biology Department. Now, she is a member of Philippine Microbiology of the Philippines and Environmental Education Network. She is a consultant and author of Science publications and books. Much of her researches are in the field of ecology and environmental studies. 